18(1): 54-61

\title{
LABORATORY STUDY OF AMMONIUM ION REMOVAL BY USING ZEOLITE (CLINOPTILOLITE) TO TREAT DRINKING WATER
}

\author{
Aušra Mažeikiene் ${ }^{1}$, Marina Valentukevičiene் ${ }^{2}$, Juozas Jankauskas ${ }^{3}$ \\ ${ }^{1,2}$ Dept of Water Management, Vilnius Gediminas Technical University, \\ Sauletekio al. 11, LT-10223 Vilnius, Lithuania \\ ${ }^{3}$ Dept of Chemistry, Vilnius Gediminas Technical University, \\ Saulètekio al. 11, LT-10223 Vilnius, Lithuania

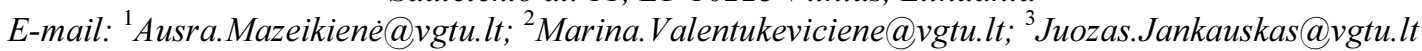 \\ Submitted 25 Nov. 2008; accepted 7 Apr. 2009
}

\begin{abstract}
Experimental investigation of ammonium ion removal from drinking water were carried out using natural zeolite (clinoptilolite) fractions of $0.3-0.6 \mathrm{~mm}$ and $0.6-1.5 \mathrm{~mm}$. Before using natural zeolite was washed and dried in an oven at a temperature of about $105^{\circ} \mathrm{C}$. Solutions with different ion power (solution 1 - supplied tap water and $\mathrm{NH}_{4} \mathrm{Cl}$, solution 2 - distillate water and $\mathrm{NH}_{4} \mathrm{Cl}$; initial concentration of ammonium ions of $2 \mathrm{mg} / l$ ) were filtrated through an experimental filter column packed with $70 \mathrm{~mm}$ and $210 \mathrm{~mm}$ of zeolite media for comparison purposes. Comparing the results for different natural zeolite fractions it was determined that the removal is more efficient using a finer fraction. After filtering $30 l$ of solution 1 through the laboratory- scaled filter column packed with $70 \mathrm{~mm}$ height of $0.3-0.6 \mathrm{~mm}$ particle size zeolite media and $0.6-1.5 \mathrm{~mm}$ particle size, the efficiency fluctuated from $89 \%$ to $70 \%$ (finer particles) and from $94 \%$ to $54 \%$ (coarser particles). Comparing the efficiency of ammonium ion removal from solutions with different ion power (solution 1 and solution 2), it was noticed that concentration reached the limit of $0.5 \mathrm{mg} / l$ in the $12^{\text {th }} l$ of solution 1 , whereas it was fifty times lower in the $12^{\text {th }} l$ of solution 2 . After filtering $10 l$ of filtrate through the filter media with the height of $210 \mathrm{~mm}$ using coarse particles, the efficiency of ammonium ion removal reached $84 \%$.
\end{abstract}

Keywords: ammonium removal, drinking water, filter media, water treatment, zeolite.

\section{Introduction}

In Lithuania only groundwater is supplied to inhabitants by water supply systems, though its quality does not always correspond to the requirements of the drinking water hygiene norm (Klimas 2002; Klimas and Gregorauskas 2002; HN 24:2003; Venkatesen and Swaminathan 2009).

The main problem is iron whose concentrations in untreated groundwater usually exceed the requirements of the hygiene norm (HN 24:2003; Juodkazis et al. 2003). However, there are cases, when the requirements are also exceeded by concentrations of ammonium ions (Klaipeda I, Klaipèda II, Kretinga, Telšiai I, Šiauliai II, Marijampolè I, Kalvarija, Preila-Pervalka, Nida, etc.).

In drinking water the maximum ammonia concentration of $1.5 \mathrm{mg} / \mathrm{l}$ is recommended by the World Health Organization to avoid changes of taste and odour of water. The current Lithuanian hygiene norm for ammonium in drinking water is $0.5 \mathrm{mg} / l$. That corresponds to the European Commission Directive where ammonia is an indicator parameter. The reasons for ammonium removal from groundwater are as follows:

a) Till ammonium ions are not removed from groundwater, manganese cannot be removed from groundwater (Sakalauskas and Valentukevičienè 2003; Štembal et al. 2005; Okoniewska et al. 2007). b) Chlorinating water with a larger quantity of ammonium ions, unpleasant scented chloramines (mono-, de- and tree chloramines) are formed.

c) The use of $\mathrm{NaClO}$ is often related to one more specific undesirable phenomenon - partial ammonium ions oxidation to nitrites whose concentration in drinking water supplied to the water supply network cannot exceed $0.5 \mathrm{mg} / l$.

d) When ammonium ions are in water, the growth of nitrifying bacteria is accelerated (Regane et al. 2003). Because of the metabolic processes of ammonium oxidizing bacteria the quantities of nitrites and organic compounds increase in water (Povilaitis 2008). Therefore, the total growth of bacteria can increase in pipelines.

Ammonium can be removed from groundwater using specific aerators (physical-chemical method). This method can be used for dissolved mineral nitrogen removal that exists in the form of ammonium ions or ammonia. That is why water is alkalized to $\mathrm{pH}$ value of $10-11$. Ammonium ions react with hydroxyl ions at such $\mathrm{pH}$ value and unsteady ammonium hydroxides are formed that decompose into gas ammonia and water:

$$
\begin{aligned}
& \mathrm{NH}_{4}^{+}+\mathrm{OH}^{-} \leftrightarrow \mathrm{NH}_{4} \mathrm{OH}, \\
& \mathrm{NH}_{4} \mathrm{OH} \leftrightarrow \mathrm{NH}_{3} \uparrow+\mathrm{H}_{2} \mathrm{O} .
\end{aligned}
$$

Alkalised water is supplied to a gas removal unit with media which is blown by air from the bottom while 
the air takes ammonia removing from the water. In this way $90-95 \%$ of ammonium nitrogen can be removed from water. This method is often applied for ammonium removal from non-organic industrial wastewater. However, this method is seldom used for ammonium removal from water. The disadvantage of this method is the necessity of neutralizing water and sometimes (when large quantities of ammonium occur in water) ammonia $\left(\mathrm{NH}_{3}\right)$ has to be removed from a gas removal unit using a blower. Besides, the efficiency of the process depends on the temperature (it has to be suitably high) and the quantity of the blown air. The need of air can be $3000 \mathrm{~m}^{3}$ for $1 \mathrm{~m}^{3}$ of water. So efficient blowers are necessary (high use of electric energy).

There is also a known method of ammonium ion removal from water, when bacteria oxidize ammonium into nitrite and then to nitrate (nitrification process) (Janda and Rudkovsky 1994; Yang 1998; Andersson et al. 2001; Miladinovic et al. 2008). The disadvantage of the method is the necessity of using additional membrane technologies at the final stage of the technology to assure the microbiological safety of drinking water (Kurama et al. 2002).

When there are extra high ammonium concentrations in water (even to $17.8 \mathrm{mg} / \mathrm{l}$ at Pervalka waterworks), its removal from water would be a better method than its nitrification, as due to unstable nitrification process ammonium can be oxidized not into nitrate but into nitrite which is more dangerous for human health (Valentukevičienè and Rimeika 2007).

Ammonium removal from drinking water is apparently a serious issue, so new methods and tools are being searched to solve it.

This investigation presents ammonium removal using natural zeolites. Zeolite was chosen as it is a natural, ecological sorbent and has no negative influence on the water quality (Sakalauskas and Valentukevičiene 2003; Mažeikienè et al. 2008). Investigation on regeneration of zeolite particles was carried out using sodium chloride as well.

Zeolites are crystalline hydrated aluminosilicates with a framework structure containing pores occupied by water and by alkali and alkaline earth cations. Due to their high cation-exchange ability as well as the molecular sieve properties, natural zeolites (being cheap materials, easily available in large quantities in many parts of the world) show special importance in water and gas purification, adsorption and catalysis (Klieve and Sekmens 1980; Park and Komarneni 1997; Rozic at al. 2000). Clinoptilolite, being a natural zeolite with the representative unit-cell formula $\left[\mathrm{AlSi}_{5} \mathrm{O}_{12}\right]_{2}\left(\mathrm{~K}_{2}, \mathrm{Na}_{2}, \mathrm{Ca}\right)$ $\left(\mathrm{H}_{2} \mathrm{O}\right)_{8}$ seems to be the most attractive material for ammonium removal from drinking water (Lebedynets et al. 2004; Inglezakis 2005; Sprinsky et al. 2005).

\section{Materials and methods}

Zeolite fractions of $0.3-0.6 \mathrm{~mm}$ and $0.6-1.5 \mathrm{~mm}$ particle sizes were used in parallel experiments. The impact of using zeolite in the filter media for ammonium removal was evaluated by comparing the concentration of ammonium in the supplied water solution with the filtered water.
Two different particle sizes of 0.3-0.6 $\mathrm{mm}$ and $0.6-$ $1.5 \mathrm{~mm}$ (separated by calibrated sieves) of natural zeolite were used in this experimental investigation on removal of ammonium ions from drinking water. Zeolite from the Sokyrnytskaya deposit (the Transcarpathian region, Ukraine) containing $70-75 \%$ of clinoptilolite was used in this study. Granulated natural zeolite was washed with distillate water for undesirable turbidity removal and dried in a laboratory oven at a temperature of $105^{\circ} \mathrm{C}$.

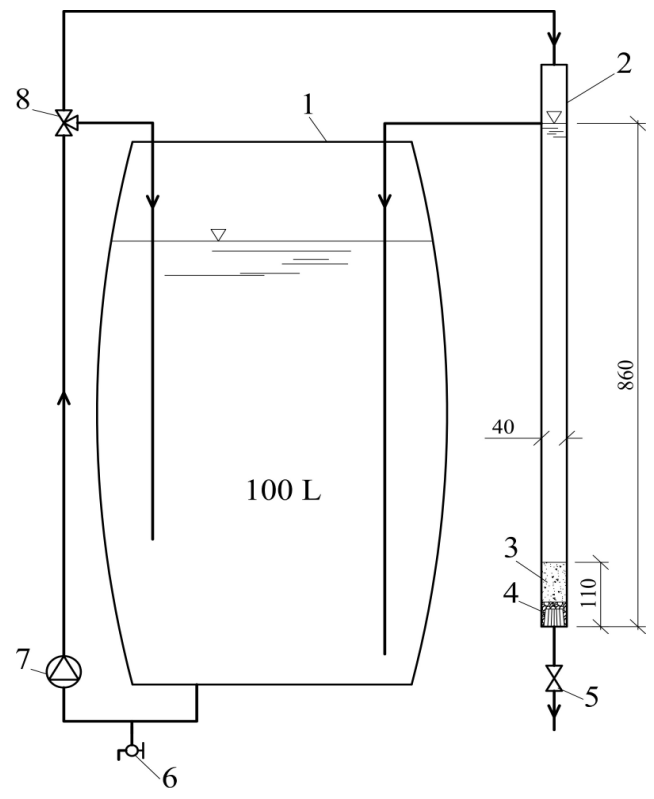

Fig. 1. Scheme of filter model: 1 - reservoir for storage of investigated water; 2 - filtration column; 3 - layer of zeolite media; 4 - supportive layer (4.0-10.0 mm size of zeolite particles); 5 - regulation valve of filtration rate; $6-$ sampling tap; 7 - pump; 8 - mixing valve

Drinking water supplied for Vilnius city (Lithuania) was used for the investigation. The quality of supplied tap water was as follows: $\mathrm{pH} \sim 7.6$; specific electric conductivity $(\mathrm{SEC}) \sim 514 \mu \mathrm{S} / \mathrm{cm} ; \mathrm{Fe}_{\text {total }} \sim 0.04 \mathrm{mg} / \mathrm{l} ; \mathrm{NH}_{4}^{+} \sim$ $0.009 \mathrm{mg} / l ; \mathrm{Mn}<6 \mu \mathrm{g} / l ; \mathrm{Na} \sim 13 \mathrm{mg} / l ; \mathrm{K} \sim 5 \mathrm{mg} / l$; dry residual $\sim 306 \mathrm{mg} / l$. Commercially available for laboratory use $\mathrm{NH}_{4} \mathrm{Cl}$ was mixed with supplied tap water. Initial concentration of ammonium ions in water was equal to $2 \mathrm{mg} / \mathrm{l}$. Distillate water with ammonium ion concentration of $2 \mathrm{mg} / \mathrm{l}$ was used for the experiments.

A laboratory-scaled filter column was equipped with water mixture from a reservoir (volume of $100 l$ ), a pump for mixture supply to the filter column, a filter column (height of $0.86 \mathrm{~m}$, diameter of $0.04 \mathrm{~m}$ ) packed with $70 \mathrm{~mm}$ and $210 \mathrm{~mm}$ in height of granular zeolite filter media for comparison purposes (Fig. 1).

Constant filtration rate of $5 \mathrm{~m} / \mathrm{h}$ was conducted during the experiments. Samples of initial solution and filtrate were taken for measurements every hour.

The quantitative results are presented as the arithmetic mean of six independent measurements $(x \pm \mathrm{SD}, n=6)$. Significant differences $(p<0.05)$ were removed from the result estimations and the measurements were analysed once again. 
The data from the experimental investigation were statistically calculated from the registered analyses. The concentration of substances $\left(\mathrm{Fe}, \mathrm{Mn}\right.$ and $\mathrm{NH}_{4}{ }^{+}$) was measured 11 times in raw water, in sampling taps and in filtered water. The average concentration at typical points was:

$$
\bar{c}=\frac{1}{n} \sum_{i-1}^{k} c_{i} m_{i},
$$

where $c_{i}$ - concentration of substances at typical points; $m_{i}$ - probability at the occurrence of concentration; $n-$ number of days; $k$ - number of different values of the concentration.

The average concentrations of substances, mentioned above, at the characteristical point were also calculated. The standard statistical estimation error of the arithmetic average was approximatly $11 \%$.

A spectrophotometric method with the German test MERK for ammonium ions was used for the determination of ammonium ion concentrations. SEC and $\mathrm{pH}$ values were determined using $\mathrm{pH}$-meter " $\mathrm{pH} 323$ " and conductivity meter "Cond $315 \mathrm{i}$ ".

Granulated zeolite filter media was regenerated using $10 \%$ of $\mathrm{NaCl}$ solution (2 litres were used for the column of $70 \mathrm{~mm}$ in height; $6 l$ were used for the column of $210 \mathrm{~mm}$ in height; filtration rate was $5 \mathrm{~m} / \mathrm{h}$ ). After regeneration procedure the zeolite filter media was washed with distillate water till filtered water reaches the conductivity of $20 \mu \mathrm{S} / \mathrm{cm}$ or less.

The filter column with granulated zeolite media experiments were conducted continuously. Zeolite filter media comparative study scenarios included:

1. Conventional supplied tap water mixture filtration through the laboratory-scaled filter column packed with $70 \mathrm{~mm}$ height of $0.3-0.6 \mathrm{~mm}$ particle size zeolite media and of $0.6-1.5 \mathrm{~mm}$ particle size for comparison purpose (initial ammonium concentration was $2 \mathrm{mg} / \mathrm{l}$, filtration rate was $5 \mathrm{~m} / \mathrm{h}$ in both cases).

2. Distillate water mixture filtration through the laboratory-scaled filter column packed with $70 \mathrm{~mm}$ height of 0.6-1.5 mm particle size for comparison purpose with the first scenario (initial ammonium concentration was $2 \mathrm{mg} / \mathrm{l}$, filtration rate was $5 \mathrm{~m} / \mathrm{h}$ ).

3. Supplied tap water mixture filtration through the laboratory-scaled filter column packed with $210 \mathrm{~mm}$ height of $0.6-1.5 \mathrm{~mm}$ particle size for comparison purpose with the first scenario (initial ammonium concentration was $2 \mathrm{mg} / l$, filtration rate was $5 \mathrm{~m} / \mathrm{h}$ ).
Three repeated experiments were performed for each operational scenario. Each experiment consisted of one control (without regeneration procedure) filter run followed by one experimental (with zeolite filter media regeneration) filter run, the latter defined by the operational scenario. Each control run generated filtered water for the sample measurement run. Experimental runs were performed directly after control runs, so that possible differences in filtration performance could be attributed to the effects of partial regeneration rather than changes in source water quality. Collected filtered water was immediately analysed by the experimental unit in the laboratory. Ammonium concentration and conductivity were measured in the collected filtered water and supplied water from a primary solution mixture reservoir.

\section{Results and discussion}

The following four tables present the results of the experimental investigation.

The data in the tables show that both sorbent and zeolite particle fractions $(0.3-0.6 \mathrm{~mm}$ and $0.6-1.5 \mathrm{~mm})$ were removing ammonium ions from water solution successfully. The results obtained filtering the solution of supplied tap water and $\mathrm{NH}_{4} \mathrm{Cl}$ through two filter media of the same $70 \mathrm{~mm}$ height with different size $(0.3-0.6 \mathrm{~mm}$ and $0.6-$ $1.5 \mathrm{~mm}$ ) of zeolite particles are compared in Fig. 2.

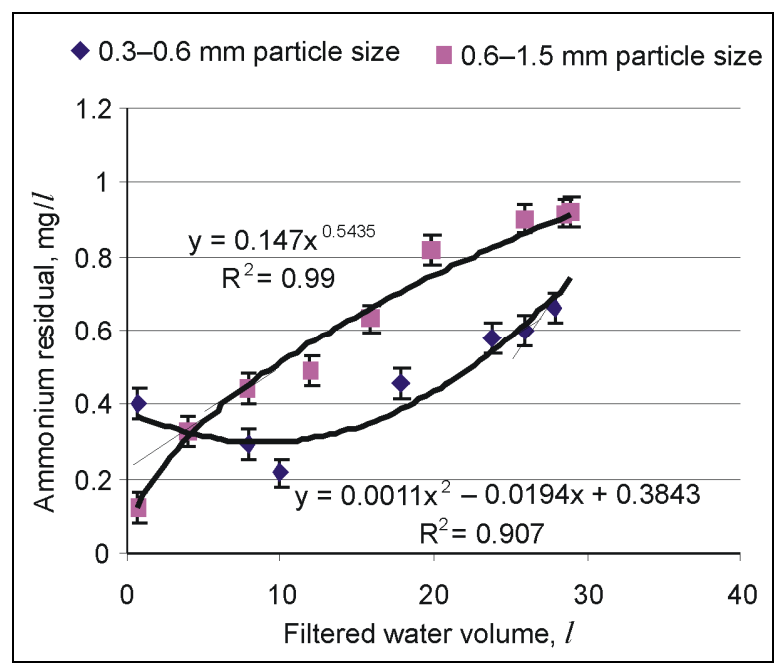

Fig. 2. Dependency of ammonium concentration in filtered water on volume of treated water

Table 1. Ammonium ion sorption in zeolite filter media of a height of $70 \mathrm{~mm}$ with particle size of $0.3-0.6 \mathrm{~mm}$ (solution mixture of tap water and $\mathrm{NH}_{4} \mathrm{Cl}$ )

\begin{tabular}{|c|c|c|c|c|c|}
\hline Start / Stand by time & $\begin{array}{l}\text { Filtration } \\
\text { run, h }\end{array}$ & $\begin{array}{l}\text { Filtered water } \\
\text { volume, } l\end{array}$ & $\begin{array}{l}\text { Residual concentration, } \\
\mathrm{mg} / \mathrm{l}\end{array}$ & $\begin{array}{l}\text { Concentracion } \\
\text { reduction, } \mathrm{mg} / \mathrm{l}\end{array}$ & $\begin{array}{c}\text { Removal efficiency, } \\
\%\end{array}$ \\
\hline $\begin{array}{l}11 \text { Jan. } 2007 \\
\text { Start } 14.00\end{array}$ & 0.09 & 1.00 & 0.400 & 1.600 & 80.0 \\
\hline Stand by 17.30 & 3.50 & 27.80 & 0.644 & 1.356 & 67.8 \\
\hline $\begin{array}{l}12 \text { Jan. } 2007 \\
\text { Start } 9.30\end{array}$ & 0.01 & 27.83 & 0.484 & 1.516 & 75.8 \\
\hline Stand by 17.00 & 7.50 & 87.43 & 1.265 & 0.735 & 36.8 \\
\hline $\begin{array}{l}15 \text { Jan. } 2007 \\
\text { Start } 9.30\end{array}$ & 0.01 & 87.50 & 0.886 & 1.114 & 55.7 \\
\hline Stand by 10.40 & 1.17 & 96.73 & 0.922 & 1.078 & 53.9 \\
\hline
\end{tabular}


Table 2. Ammonium ion sorption in zeolite filter media of a height of $70 \mathrm{~mm}$ with particle size of $0.6-1.5 \mathrm{~mm}$ (solution mixture of tap water and $\mathrm{NH}_{4} \mathrm{Cl}$ )

\begin{tabular}{|c|c|c|c|c|c|}
\hline Start / Stand by time & $\begin{array}{l}\text { Filtration } \\
\text { run, h }\end{array}$ & $\begin{array}{l}\text { Filtered water } \\
\text { volume, } l\end{array}$ & $\begin{array}{l}\text { Residual concentration, } \\
\mathrm{mg} / \mathrm{l}\end{array}$ & $\begin{array}{l}\text { Concentracion } \\
\text { reduction, } \mathrm{mg} / \mathrm{l}\end{array}$ & Removal efficiency, $\%$ \\
\hline $\begin{array}{l}\text { 22 Jan. } 2007 \\
\text { Start } 13.00\end{array}$ & 0.09 & 1.00 & 0.123 & 1.877 & 93.9 \\
\hline Stand by 16.50 & 3.83 & 30.45 & 0.917 & 1.083 & 54.2 \\
\hline $\begin{array}{l}\text { 23 Jan. } 2007 \\
\text { Start } 9.45\end{array}$ & 0.05 & 30.50 & 0.320 & 1.680 & 84.0 \\
\hline Stand by 18.00 & 8.25 & 96.04 & 1.210 & 0.790 & 39.5 \\
\hline $\begin{array}{l}\text { 24 Jan. } 2007 \\
\text { Start } 8.45\end{array}$ & 0.06 & 96.50 & 0.688 & 1.312 & 65.6 \\
\hline Stand by 9.30 & 0.75 & 101.98 & 0.785 & 1.215 & 60.8 \\
\hline $\begin{array}{l}\text { 25 Jan. } 2007 \\
\text { Start } 11.30\end{array}$ & 0.50 & 106.44 & 0.964 & 1.036 & 51.8 \\
\hline Stand by 14.45 & 3.25 & 128.30 & 1.191 & 0.809 & 40.5 \\
\hline $\begin{array}{l}\text { 26 Jan. } 2007 \\
\text { Start } 9.25\end{array}$ & 0.08 & 128.94 & 0.833 & 1.167 & 58.4 \\
\hline Stand by 12.15 & 2.83 & 150.81 & 1.349 & 0.651 & 32.6 \\
\hline \multicolumn{6}{|c|}{29 Jan. 2007 zeolite media was regenerated using $2110 \% \mathrm{NaCl}$ solution } \\
\hline $\begin{array}{l}29 \text { Jan. } 2007 \\
\text { Start } 11.15\end{array}$ & 0.08 & 151.45 & 0.526 & 1.474 & 73.7 \\
\hline Stand by 14.45 & 3.50 & 178.78 & 1.283 & 0.717 & 35.9 \\
\hline $\begin{array}{l}30 \text { Jan. } 2007 \\
\text { Start } 8.00\end{array}$ & 0.25 & 180.77 & 0.656 & 1.344 & 67.2 \\
\hline Stand by 8.45 & 0.75 & 184.75 & 0.935 & 1.065 & 53.3 \\
\hline
\end{tabular}

Table 3. Ammonium ion sorption in zeolite filter media of a height of $70 \mathrm{~mm}$ with particle size of $0.6-1.5 \mathrm{~mm}$ (solution mixture of distillate water and $\mathrm{NH}_{4} \mathrm{Cl}$ )

\begin{tabular}{l|c|c|c|c|c}
\hline Start / Stand by time & $\begin{array}{c}\text { Filtration } \\
\text { run, } \mathrm{h}\end{array}$ & $\begin{array}{c}\text { Filtered water } \\
\text { volume, } 1\end{array}$ & $\begin{array}{c}\text { Residual concentration, } \\
\mathrm{mg} / \mathrm{l}\end{array}$ & $\begin{array}{c}\text { Concentracion } \\
\text { reduction, } \mathrm{mg} / \mathrm{l}\end{array}$ & $\begin{array}{c}\text { Removal efficiency, } \\
\%\end{array}$ \\
\hline 21 Feb. 2007 & 0.13 & 1.00 & 0.001 & 1.999 & 1.995 \\
Start 10.15 & 1.38 & 10.97 & 0.005 & 1.982 & 99.9 \\
& 1.88 & 14.95 & 0.018 & 1.912 & 99.8 \\
Stand by 16.40 & 4.88 & 38.80 & 0.088 & 1.858 & 95.6 \\
\hline
\end{tabular}

Table 4. Ammonium ion sorption in zeolite filter media of a height of $210 \mathrm{~mm}$ with particle size of $0.6-1.5 \mathrm{~mm}$ (solution mixture of tap water and $\mathrm{NH}_{4} \mathrm{Cl}$ )

\begin{tabular}{|c|c|c|c|c|c|}
\hline $\begin{array}{l}\text { Start / Stand by } \\
\text { time }\end{array}$ & $\begin{array}{l}\text { Filtration } \\
\text { run, h }\end{array}$ & $\begin{array}{l}\text { Filtered water } \\
\text { volume, } l\end{array}$ & $\begin{array}{l}\text { Residual concentration, } \\
\mathrm{mg} / \mathrm{l}\end{array}$ & $\begin{array}{l}\text { Concentracion } \\
\text { reduction, } \mathrm{mg} / \mathrm{l}\end{array}$ & $\begin{array}{c}\text { Removal efficiency, } \\
\%\end{array}$ \\
\hline 1 & 2 & 3 & 4 & 5 & 6 \\
\hline $\begin{array}{l}30 \text { Jan. } 2007 \\
\text { Start } 9.45\end{array}$ & 0.25 & 1.99 & 0.065 & 1.935 & 96.8 \\
\hline Stand by 19.15 & 9.5 & 75.53 & 0.580 & 1.420 & 71.0 \\
\hline $\begin{array}{l}\text { 31 Jan. } 2007 \\
\text { Start } 8.15\end{array}$ & 0.25 & 77.52 & 0.255 & 1.745 & 87.3 \\
\hline Stand by 18.15 & 10.0 & 157.02 & 0.853 & 1.147 & 57.4 \\
\hline $\begin{array}{l}01 \text { Feb. } 2007 \\
\text { Start } 9.50\end{array}$ & 0.17 & 158.37 & 0.465 & 1.535 & 76.8 \\
\hline Stand by 18.50 & 9.0 & 229.92 & 1.284 & 0.716 & 35.8 \\
\hline $\begin{array}{l}02 \text { Feb. } 2007 \\
\text { Start } 9.00\end{array}$ & 0.08 & 230.58 & 0.810 & 1.190 & 59.5 \\
\hline Stand by 19.00 & 10.0 & 310.08 & 1.738 & 0.262 & 13.1 \\
\hline $\begin{array}{l}\text { 07 Feb. } 2007 \\
\text { Start } 9.00\end{array}$ & 0.25 & 312.07 & 0.977 & 1.023 & 51.2 \\
\hline Stand by 20.00 & 11.0 & 399.52 & 1.898 & 0.102 & 5.1 \\
\hline $\begin{array}{l}08 \text { Feb. } 2007 \\
\text { Start } 10.30\end{array}$ & 0.08 & 400.16 & 1.363 & 0.637 & 31.9 \\
\hline Stand by 18.00 & 7.5 & 459.15 & 1.98 & 0.020 & 1.0 \\
\hline
\end{tabular}


Continue Table 4

\begin{tabular}{|c|c|c|c|c|c|}
\hline 1 & 2 & 3 & 4 & 5 & 6 \\
\hline \multicolumn{6}{|c|}{$13 \mathrm{Feb} .2007$ zeolite media was regenerated using $6110 \% \mathrm{NaCl}$ solution } \\
\hline 14 Feb. 2007 & 0.13 & 460.80 & 0.828 & 1.172 & 58.6 \\
\hline \multirow[t]{4}{*}{ Start 8.00} & 0.39 & 462.80 & 0.468 & 1.532 & 76.6 \\
\hline & 0.78 & 465.81 & 0.367 & 1.633 & 81.7 \\
\hline & 1.30 & 469.81 & 0.346 & 1.654 & 82.7 \\
\hline & 1.95 & 474.80 & 0.353 & 1.647 & 82.4 \\
\hline Stand by 11.15 & 3.25 & 484.81 & 0.482 & 1.518 & 75.9 \\
\hline
\end{tabular}

Fig. 2 shows that after 30 litres of solution was filtered through the granulated zeolite filter media when the particle size was $0.3-0.6 \mathrm{~mm}$, the ammonium ion concentration of $0.644 \mathrm{mg} / l$ was determined in filtrated water, whereas using the particles of $0.6-1.5 \mathrm{~mm}$ the concentration of ammonium ions reached $0.917 \mathrm{mg} / \mathrm{l}$. The limit of ammonium ion concentration of $0.5 \mathrm{mg} / \mathrm{l}$ was exceeded in the $15^{\text {th }} l$ of filtered water when the filter media with coarser particles was used. The result shows that both zeolite particle fractions removed ammonium ions from water solution successfully, though using finer particles for filter media a lower concentration of $\mathrm{NH}_{4} \mathrm{Cl}$ was determined in filtered water. It was noticed that using filter media with particles of $0.3-0.6 \mathrm{~mm}$ ammonium ion concentration in the first ten litres of filtrated water decreased firstly and then increased according to polynomial dependency $\left(\mathrm{R}^{2}=0.907\right)$. The reason could be the turbidity of the first litres of filtrated water, which was noticed when the process of filtrating was not stable and finer particles were used for the filter media. After filtering $30 l$ of solution (for each fraction) through two fractions, both of them were of $70 \mathrm{~mm}$ in height, with different particle size (initial ammonium ion concentration of $2 \mathrm{mg} / \mathrm{l}$ ) the efficiency of ammonium ion removal fluctuated from $89 \%$ to $70 \%$ (finer particles) and from $94 \%$ to $54 \%$ (coarser particles). After measuring the conductivity in the initial content and in the filtrates, it was noticed, that the conductivity was rather stable, so ammonium ion removal from filtered water was likely caused by the exchange of ions. Sodium, potassium and calcium ions, that are zeolite components, were replaced by ammonium ions during the workload of the filter. Therefore, the conductivity indicator in the filtrate remained similar to the conductivity indicator at the initial solution. Value of $\mathrm{pH}$ of 8 was measured in the initial content as well as in filtrates and it fluctuated marginally. Using coarse zeolite particles $(0.6-1.5 \mathrm{~mm})$ in the filter media for ammonium ion sorption, the concentration of $\mathrm{NH}_{4}^{+}$increased according to power dependency $\left(\mathrm{R}^{2}=0.907\right)$.

Further experiments compare ammonium ion sorption from water solution with different ion capacity filtering it through the media with coarse particles (the initial ammonium ion concentration was equal to $2 \mathrm{mg} / \mathrm{l}$; solution 1 prepared of supplied tap water and $\mathrm{NH}_{4} \mathrm{Cl}$; solution 2 prepared of distillate water and $\mathrm{NH}_{4} \mathrm{Cl}$ ). The obtained results are presented in Fig. 3.

According to Fig. 3, after filtering $50 \mathrm{l}$ of each solution through the zeolite media with coarse particles, different results were obtained. The ammonium ion concentration was equal to $0.14 \mathrm{mg} / l$ in the $15^{\text {th }} l$ of solution 2 and $1.31 \mathrm{mg} / l$ in the $15^{\text {th }} l$ of solution 1 . Besides, ammo- nium ion sorption of distillate water solution was carried out according to the power dependency $\left(\mathrm{R}^{2}=0.991\right)$, whereas ammonium ion sorption of water supply solution was carried out according to the polynomial dependency $\left(\mathrm{R}^{2}=0.992\right)$. The ammonium ion concentration of $0.5 \mathrm{mg} / l$ was reached in the $12^{\text {th }} l$ of solution 1 (water supply), whereas ammonium ion concentration in the $12^{\text {th }} l$ of solution 2 reached only $0.01 \mathrm{mg} / l$. Comparing the removal of ammonium ion from two solutions (initial ammonium ions concentration of $2 \mathrm{mg} / l$ ) it was noticed that ammonium ions were more efficiently removed from solution 2. After filtering $50 l$ of each solution through the zeolite fraction filter of $70 \mathrm{~mm}$ in height with coarse particles $(0.6-1.5 \mathrm{~mm})$, the efficiency of ammonium ion removal fluctuated from $94 \%$ to $65 \%$ in solution 1 and from $99 \%$ to $93 \%$ in solution 2 . Worse results were obtained using supplied tap water because other positive ions of tap water participated in ammonium ion exchange.

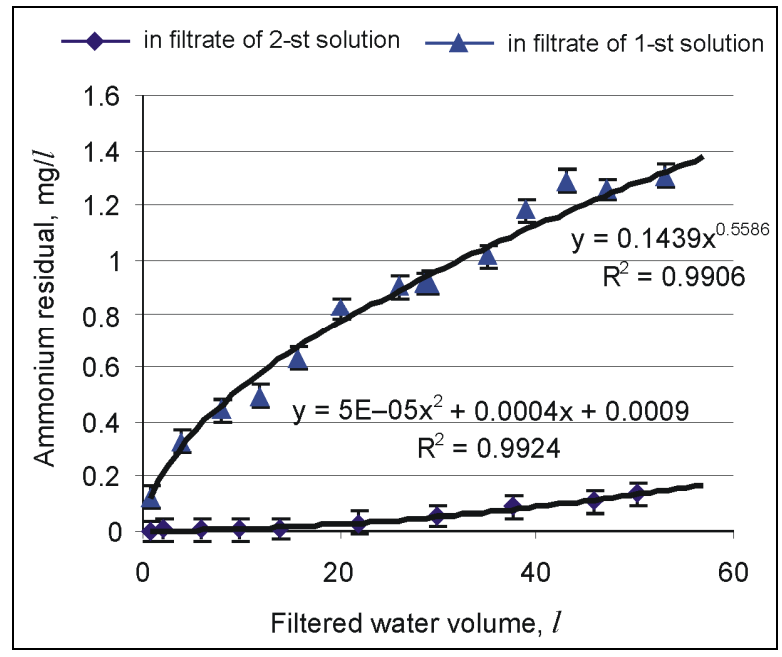

Fig. 3. Differences between ammonium concentration in filtered solution 1 and solution 2

The efficiency of ammonium ion removal from water solutions using two zeolite fractions media are presented in Fig. 4.

The data in Fig. 4 show that the efficiency of ammonium ion sorption from water solutions decreases following the time run in all the cases. After six-hour filtration the changes of the efficiency of $\mathrm{NH}_{4}^{+}$(99.9$94.2 \%$ ) from solution 2 (distillate water) were the least. It was noticed that the efficiency of $\mathrm{NH}_{4} \mathrm{Cl}$ removal using solution of tap water and $\mathrm{NH}_{4} \mathrm{Cl}$ was not so high (67$89 \%$, finer particles and 55-93\%, coarser particles). 


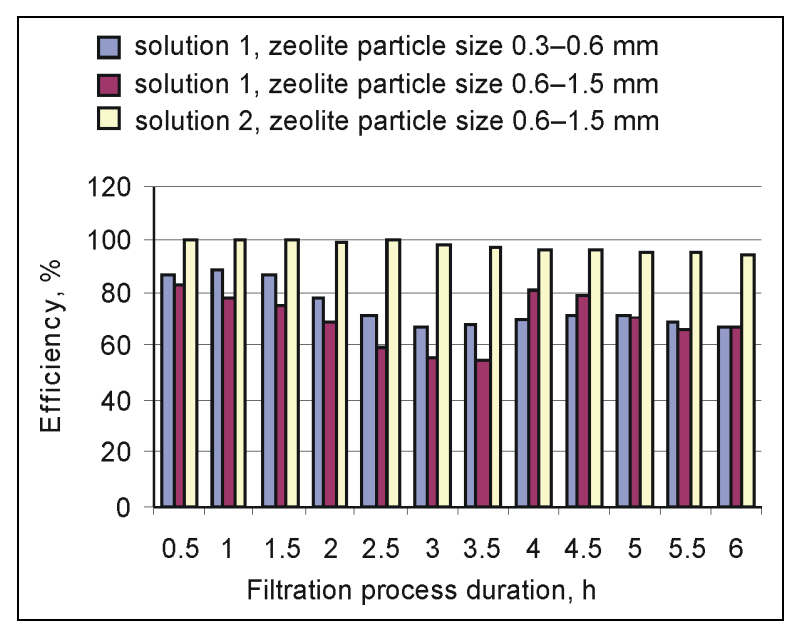

Fig. 4. Efficiency of ammonium removal at different running time

It was observed that the efficiency of ammonium ion sorption in solution 1 varied when the filter model was switched off for some time (night, weekend) and the filtering process was disturbed. After the interval the efficiency of ammonium ion removal from water increased (Fig. 4, Tables 1-4). Searching the phenomenon of the increase of the efficiency of $\mathrm{NH}_{4}$ removal after the interval, further studies were carried out with fraction media packed with coarser particles. Coarser particles were chosen because of the industrial convenience to use coarse particles for fraction media for treating drinking water. The results of the experiments showed that ammonium ions were removed from water using coarse particles $(0.6-1.5 \mathrm{~mm})$ only marginally less efficiently than using finer particles $(0.3-0.6 \mathrm{~mm})$. According to further studies, ammonium ion concentration increased when the quantity of filtered water increased, though after switching off the filter model for a night or a weekend (after filtering 75, $140,212,289$ and $377 l$ ) ammonium ion concentration decreased noticeably. It was determined that after switching on the filter model after 14-hour interval ammonium ion concentration was by $0.43 \mathrm{mg} / \mathrm{l}$ lower than before the interval. The phenomenon can be explained by partial regeneration of zeolite media because $\mathrm{Na}^{+}, \mathrm{K}^{+}$, $\mathrm{Ca}^{2+}$ ions were present in solution 1 as it was prepared using tap water.

Filter model media was regenerated filtering it with $10 \%$ of sodium chloride when the filtration rate was $5 \mathrm{~m} / \mathrm{h}$. After that the media were rinsed with distillate water. Then solution 1 was filtered again. The obtained results are presented in Figs. 5 and 6.

It was noticed that ammonium ion concentration in regenerated filter media was lower. Using coarser particles for filter media (height of $70 \mathrm{~mm}$ ), the difference of ammonium ion concentrations was $0.823 \mathrm{mg} / \mathrm{l}$, whereas using filter media with the height of $210 \mathrm{~mm}$ (particles of the same size) the difference of ammonium ion concentration was $1.152 \mathrm{mg} / \mathrm{l}$. Better results were obtained when three times higher filtering media was regenerated using three times bigger quantity of $10 \%$ of sodium chloride than the results using the media with the height of $70 \mathrm{~mm}$. It was also noticed that after regenerating filte- ring media with the height of $210 \mathrm{~mm}$ and starting filtering solution 1 , the ammonium concentration in the first $10 l$ of filtrate was decreasing. The concentration reached the limit of $0.32 .5 \mathrm{mg} / l$ in the $11^{\text {th }} l$ of filtrate and then was gradually increasing, the same as it was before regeneration. The conclusion is that a bigger quantity of zeolite particle filter media can be easier regenerated. After the filtering process is stable the ammonium ion removal is more efficient (11 litres of solution was filtrated in $1.4 \mathrm{~h})$. The ammonium concentration decreased to $1.675 \mathrm{mg} / l$ when the initial concentration was $2 \mathrm{mg} / \mathrm{l}$. When the ability of ammonium ions to exchange is too low, they can be regenerated using the solution of $\mathrm{NaCl}$. After filtering 10 litres of filtrate through the filter media with the height of $210 \mathrm{~mm}$ using coarse particles, the efficiency of ammonium ions removal reached $84 \%$.

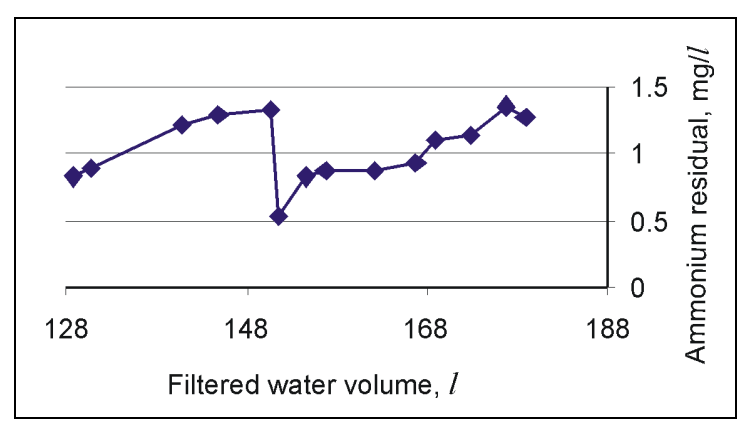

Fig. 5. Dependency of ammonium concentration on the volume of filtered water before and after regeneration of filter media of $70 \mathrm{~mm}$ height using $\mathrm{NaCl}$ solution

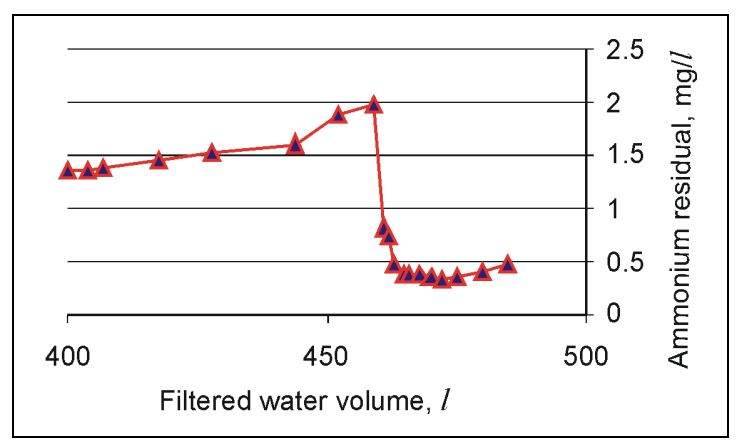

Fig. 6. Dependency of ammonium concentration on the volume of filtered water before and after regeneration of filter media of $210 \mathrm{~mm}$ height using $\mathrm{NaCl}$ solution

The fact, that zeolite particle media were successfully regenerated using $\mathrm{NaCl}$ solution, confirmed the presumption that ammonium ions were removed from the solutions due to exchange of potassium ions (that are components of zeolite) with ammonium ions from water. Small quantities of $\mathrm{Na}^{+}$ions that accidentally passed into filtrate could not have any negative effect on the quality of drinking water as ammonium ion concentration in solution 1 was $13 \mathrm{mg} / \mathrm{l}$, whereas the hygiene norm HN 24:2003 permits ammonium ion concentration of $200 \mathrm{mg} / \mathrm{l}$. To a conclusion, both tested fractions of zeolite particle media can be used for an efficient removal of ammonium ions from water that is treated as drinking water and where all the other indicators are similar to tested water. 


\section{Conclusions}

1. The laboratory experiment with a model of two natural zeolite fraction media with different zeolite particle size of $0.3-0.6 \mathrm{~mm}$ and $0.6-1.5 \mathrm{~mm}$ gave possibility of ammonium ion removal from water solutions when water was treated for drinking purposes.

2. After filtering 30 litres of solution 1 (initial ammonium ion concentration was $2 \mathrm{mg} / \mathrm{l}$ ) through a laboratory-scaled filter column packed with $70 \mathrm{~mm}$ height of $0.3-0.6 \mathrm{~mm}$ particle size zeolite media and $0.6-1.5 \mathrm{~mm}$ particle size, the efficiency fluctuated from $89 \%$ to $70 \%$ (finer particles) and from $94 \%$ to $54 \%$ (coarser particles).

3 . After measuring conductivity at the initial content and filtrates, it was noticed that it changed marginally. The presumption is that the removal of ammonium ions was carried out due to exchange of ions (ammonium ions were replaced by $\mathrm{Na}^{+}, \mathrm{K}^{+}$and $\mathrm{Ca}^{+}$ions that are components of zeolite).

4. Comparing ammonium ion removal from two solutions (solution 1 - supplied tap water and $\mathrm{NH}_{4} \mathrm{Cl}$; solution 2 - distillate water and $\mathrm{NH}_{4} \mathrm{Cl}$; initial ammonium concentration of $2 \mathrm{mg} / l$ ), it was noticed that ammonium ion removal from solution 2 was significantly more efficient. After filtrating 50 litres of both solutions through media packed with $70 \mathrm{~mm}$ height of coarser particle (0.6$1.5 \mathrm{~mm}$ ) zeolite media, the efficiency of ammonium ion removal fluctuated from $94 \%$ to $65 \%$ (solution 1) and from $99 \%$ to $93 \%$ (solution 2 ).

5. When the ability of ammonium ions to exchange is too low, they can be regenerated using the solution of $\mathrm{NaCl}$. After filtering 10 litres of filtrate through the filter media with the height of $210 \mathrm{~mm}$ using coarse particles, the efficiency of ammonium ion removal reached $84 \%$.

6. However, such processes still need to be proved in more extensive investigations, but these study results could be applied as a basic scenario.

\section{References}

Andersson, A.; Laurent, P.; Kihn, A.; Prevost, M.; Servais, P. 2001. Impact of temperature on nitrification in biological activated carbon (BAC) filters used for drinkingwater treatment, Water Research 35(12): 2923-2934. doi:10.1016/S0043-1354(00)00579-0

HN 24:2003. Geriamojo vandens saugos ir kokybès reikalavimai [Requirements on Drinking Water Safety and Quality], Valstybès žinios 79-3606.

Inglezakis, V. 2005. The concept of "capacity" in zeolite ionexchange systems, Journal of Colloid and Interface Science 281: 68-79. doi:10.1016/j.jcis.2004.08.082

Yang, L. 1998. Investigation of nitrification by co-immobilized nitrifying bacteria and zeolite in a batchwise fluidized bed, Water Science and Technology 35(8): 169-175. doi:10.1016/S0273-1223(97)00164-9

Janda, A. V.; Rudkovsky, J. 1994. Removal of ammonia in drinking water by biological nitrification, $J$ Water SRTAqua 43(3): 120-125.

Juodkazis, J.; Kadūnas, K.; Klimas, A. 2003. Strategic directions and main tasks for groundwater use and protection management in Lithuania, Geologija 44: 38-47.
Klieve, J. R.; Sekmens, M. J. 1980. An evaluation of pretreated natural zeolites for ammonium removal, Water Research 14(2): 161-168. doi:10.1016/0043-1354(80)90232-8

Klimas, A. 2002. Methods of assessing impacts of urbanization on groundwater quality-Lithuanian experience. Current problems of hydrogeology in urban areas, urban agglomerations and industrial centers. NATO Science Series. IV, Earth and Environmental Sciences 8: 457-477.

Klimas, A.; Gregorauskas, M. 2002. Groundwater abstraction and contamination in Lithuania as geoindicators of environmental change, Environmental Geology 42(7): 767 772. doi:10.1007/s00254-002-0554-7

Kurama, H.; Poetzschke, J.; Haseneder, R. 2002. The application of membrane filtration for the removal of ammonium ions frobm potable water, Water Research 36(12): 2905 2909. doi:10.1016/S0043-1354(01)00531-0

Lebedynets, M.; Sprinskyy, M.; Sakhnyuk, I.; Zbytniewsky, I.; Golembiewsky, R.; Buszewsky, B. 2004. Adsorption of Ammonium Ions onto a Natural Zeolite: Transcarpathian Clinoptilolite, Adsorption Science \& Technology 22(9): 731-741. doi:10.1260/0263617043026541

Mažeikienė, A.; Valentukevičienė, M.; Rimeika, M.; Matuzevičius, A. B.; Dauknys, R. 2008. Removal of nitrates and ammonium ions from water using natural sorbent zeolite (clinoptilolite), Journal of Environmental Engineering and Landscape Management 16(1): 38-44. doi:10.3846/1648-6897.2008.16.38-44

Miladinovic, N.; Weatherley, L. R. 2008. Intensification of ammonia removal in a combined ion-exchange and nitrification column, Chemical Engineering Journal 135(1-2): 15-24. doi:10.1016/j.cej.2007.02.030

Okoniewska, E.; Lach, J.; Kacprzak, M.; Neczaj, E. 2007. The removal of manganese, iron and ammonium nitrogen on impregnated activated carbon, Desalination 206(1-3): 251-258. doi:10.1016/j.desal.2006.04.055

Park, M.; Komarneni, S. 1997. Occlusion of $\mathrm{KNO}_{3}$ and $\mathrm{NH}_{4} \mathrm{NO}_{3}$ in natural zeolites, Zeolites 18: 171-175. doi:10.1016/S0144-2449(96)00130-3

Povilaitis, A. 2008. Source apportionment and retention of nutrients and organic matter in the Merkys River Basin in Southern Lithuania, Journal of Environmental Engineering and Landscape Management 16(4):195-204. doi:10.3846/1648-6897.2008.16.195-204

Regan, J.; Harrington, G.; Baribeau, H.; De Leon, R.; Noguera, D. 2003. Diversity of nitrifying bacteria in full-scale chloraminated distribution systems, Water Research 37(1): 197205. doi:10.1016/S0043-1354(02)00237-3

Rozic, M.; Cerjan-Stefanovic, S.; Kurajica, S.; Vancinae, V.; Hodzic, E. 2000. Ammoniacal nitrogen removal from water by treatment with clays and zeolites, Water Research 34(14): 3675-3681. doi:10.1016/S0043-1354(00)00113-5

Sakalauskas, A.; Valentukevičienè, M. 2003. Investigation into the influence of natural powered zeolite on drinking water treatment at Druskininkai waterworks III, Journal of Environmental Engineering and Landscape Management 11(4): 169-178.

Sprinsky, M.; Lebedynets, M.; Terzyk, A. P.; Kowalczyk, P.; Namiesnik, J.; Buszewsky, B. 2005. Ammonium sorption from aqueous solutions by the natural zeolite Transcarpathian Clinoptilolite studied under dynamic conditions, Journal of Colloid and Interface Science 284: 408-415. doi:10.1016/j.jcis.2004.10.058 
Štembal, T.; Markič, M.; Ribičič, N.; Briški, F.; Sipos, L. 2005. Removal of ammonia, iron and manganese from groundwaters of northern Croatia-pilot plant studies, Process Biochemistry 40(1): 327-335. doi:10.1016/j.procbio.2004.01.006

Valentukevičiene, M.; Rimeika, M. 2007. Development of a fluidized batch process using natural powdered zeolite
(Clinoptilolite), Polish J. of Environ. Stud. 16(2): 283288.

Venkatesan, G.; Swaminathan, G. 2009. Review of chloride and sulphate attenuation in ground water nearby solid-waste landfill sites, Journal of Environmental Engineering and Landscape Management 17(1):195-204. doi:10.3846/1648-6897.2009.17.Ia-Ig

\title{
AMONIO JONŲ ŠALINIMO IŠ RUOŠIAMO GERIAMOJO VANDENS, NAUDOJANT CEOLITĄ (KLINOPTILOLITĄ), LABORATORINIAI TYRIMAI
}

\author{
A. Mažeikienė, M. Valentukevičienė, J. Jankauskas \\ S a n tra u a
}

Eksperimentiniai $\mathrm{NH}_{4}^{+}$šalinimo laboratorijos sąlygomis iš ruošiamo geriamojo vandens tyrimai buvo atlikti naudojant gamtinio ceolito (klinoptilolito) $0,3-0,6 \mathrm{~mm}$ ir $0,6-1,5 \mathrm{~mm}$ stambumo frakcijas. Prieš naudojant gamtinis ceolitas buvo išplautas ir išdžiovintas krosnyje apie $105^{\circ} \mathrm{C}$ temperatūroje. Pro eksperimentinio filtro ceolito užpildus (užpildo aukštis pirmuoju atveju buvo $70 \mathrm{~mm}$, antruoju $-210 \mathrm{~mm}$ ) $5 \mathrm{~m} / \mathrm{h}$ greičiu praleisti skirtingos joninès jègos tirpalai (iš vandentiekio vandens bei $\mathrm{NH}_{4} \mathrm{Cl}$ (I) ir iš distiliuoto vandens bei $\mathrm{NH}_{4} \mathrm{Cl}$ (II) pasigaminti tirpalai, kuriuose pradine amonio jonu koncentracija buvo $2,0 \mathrm{mg} / l$ ). Lyginant dviejų skirtingu gamtinio ceolito frakcijų eksperimento rezultatus nustatyta, kad smulkesnė frakcija efektyviau iš tirpalų šalina $\mathrm{NH}_{4}^{+}$. Prafiltravus po 30 litrų pirmojo tirpalo pro dvi $70 \mathrm{~mm}$ aukščio skirtingo ceolito grūdelių stambumo frakcijas, amonio jonų šalinimo iš tirpalo efektyvumas kito atitinkamai nuo $89 \%$ iki $70 \%$ (esant smulkesnei frakcijai) ir nuo $94 \%$ iki $54 \%$ (kai frakcija stambesnè). Lyginant amonio jonu šalinimo iš skirtingos joninès jẻgos tirpalų efektyvumą pastebèta, $\mathrm{kad} 0,5 \mathrm{mg} / \mathrm{l}$ amonio jonų koncentracija pirmojo tirpalo filtrate pasiekta jau dvyliktajame filtrato litre, o antrojo (II) tirpalo filtrato dvyliktajame litre ji buvo 50 kartu mažesnè. Prafiltravus pro regeneruotą $210 \mathrm{~mm}$ aukščio $0,6-1,5 \mathrm{~mm}$ stambumo ceolito grūdelių užpildą 10 litru pirmojo tirpalo, amonio jonų šalinimo iš tirpalo efektyvumas siekė $84 \%$.

Reikšminiai žodžiai: amonio šalinimas, geriamasis vanduo, filtro užpildas, vandens ruošimas, ceolitas.

\section{ЭКСПЕРИМЕНТАЛЬНЫЕ ИССЛЕДОВАНИЯ ОЧИСТКИ ПИТЬЕВОЙ ВОДЫ ОТ ИОНОВ АММОНИЯ, ИСПОЛЬЗУЯ ЦЕОЛИТ (КЛИНОПТИЛОЛИТ), В ЛАБОРАТОРНЫХ УСЛОВИЯХ}

А. Мажейкене, М. Валентукявичене, Ю. Янкаускас

Р е 3 ю м е

Экспериментальные исследования очистки питьевой воды от ионов аммония проводились в лабораторных условиях, используя природный цеолит (клиноптилолит) с содержанием фракции 0,3-0,6 мм и 0,6-1,5 мм. Перед использованием природный цеолит был промыт и высушен в печи при температуре $105{ }^{0} \mathrm{C}$. Растворы различного ионного заряда (1-й раствор из водопроводной воды и $\mathrm{NH}_{4} \mathrm{Cl}$ и 2-й раствор из дистиллированной воды и $\mathrm{NH}_{4} \mathrm{Cl}$, в которых первичная концентрация ионов аммония была 2,0 мг/л) были пропущены через цеолитовую загрузку экспериментального фильтра со скоростью 5 м/ч (высота загрузки в первом случае составляла 70 мм, во втором 210 мм). При сравнении результатов эксперимента с двумя различными фракциями природного цеолита обнаружено, что мелкозернистая фракция эффективнее очищает растворы от NH4+. После фильтрования 30 л первичного раствора обеими фракциями различной зернистости цеолита эффективность очистки раствора от ионов аммония достигала соответственно от $70 \%$ до $89 \%$ (мелкозернистой фракции) и от $54 \%$ до 94\% (крупнозернистой фракции). При сравнении результатов удаления ионов аммония из 1-го и 2-го растворов с разными ионными зарядами в 12-м литре 1-го раствора была обнаружена концентрация ионов аммония в 0,5 мг/л, что в 50 раз меньше, чем в 12-м литре профильтрованного 2-го раствора. После того, как было профильтровано 10 л первого раствора через регенерированную цеолитовую загрузку высотой в 210 мм (фракция 0,6-1,5 мм), эффект очистки раствора от ионов аммония достигал $84 \%$.

Ключевые слова: удаление аммония, питьевая вода, загрузка фильтра, водоподготовка, цеолит.

Aušra MAŽEIKIENĖ. Dr, Assoc. Prof., Dept of Water Management, Vilnius Gediminas Technical University (VGTU), Sauletekio al. 11, LT-10223 Vilnius, Lithuania.

Doctor of Science (environmental engineering), VGTU, 2005. Publications: author of more than 15 research papers. Research interests: water treatment, ecotechnologies for water management.

Marina VALENTUKEVIČIENĖ. Dr, Assoc. Prof., Dept of Water Management, Vilnius Gediminas Technical University (VGTU), Saulètekio al. 11, LT-10223 Vilnius, Lithuania.

Doctor of Science (environmental engineering), VGTU, 2003. Publications: author of more than 20 research papers. Research interests: water treatment, ecotechnologies for water management.

Juozas JANKAUSKAS. Dr, Assoc. Prof., Dept of Chemistry, Vilnius Gediminas Technical University (VGTU), Saulètekio al. 11, LT-10223 Vilnius, Lithuania.

Doctor of Science (analytic chemistry), VISI, 1972. Publications: author of more than 80 research papers. Research interests: environmental analytic chemistry, drinking water treatment technologies. 